\title{
Anders Behring Breiviks politiska hemvist och motivbild. Sakkunnigrapport inför rättegången i Oslo, 4 juni 2012
}

\section{Mattias Gardell}

SAMMANDRAG: När Mattias Gardell kallades som sakkunnigt expertvittne till rättegången mot Anders Behring Breivik var uppdraget att blottlägga Breiviks politiska idévärld. Gardells granskning visar att Breivik primärt var influerad av tre tankeströmningar: antimuslimsk rasism (islamofobi), kulturkonservativ nationalism och antifeminism. Till detta hade Breivik fogat bärande element från vitmaktideologi, högerkristen teologi och tempelriddartraditionen, vilket inramades av ett romantiskt maskulint krigarideal. Gardell visar också att Breivik inte var ensam om sin politiska världsbild och att den kan identifieras som fascistisk. Han betonar att Breiviks spektakulära våld var en performativ handling som avsåg skapa vad den hänvisade till: ett heroiskt avantgarde av manliga korsriddare som skulle rena nationen från den inre fienden (kulturmarxister, multikulturalister, feminister) och besegra den yttre fienden (muslimer) som ett preludium i en nationell pånyttfödelse. Gardells sakkunnigrapport ingick i ett block om sex experter som kallats in för att granska Breiviks politiska filosofi och fascismens idéhistoria, och fick stor betydelse för rättens bedömning. Den 24 augusti 2012 förklarades Breivik juridiskt ansvarig för sina handlingar och dömdes till lagens strängaste straff.

NYCKELORD: Anders Behring Breivik; fascism; ledarlöst motstånd; kontrajihadister; islamofobi; kulturkonservatism; antifeminism; vitmaktideologi; högerkristen teologi.

PUBLICERINGSHISTORIK: Gardells sakkunnigrapport vid Breivikrättegången i Oslo den 4 juni 2012 med nyskrivet för- och efterord av författaren.

MATTIAS GARDELL är professor i jämförande religionsvetenskap vid Uppsala universitet.

\section{FÖRSLAG PÅ KÄLLANGIVELSE:}

Gardell, Mattias (2013) "Anders Behring Breiviks politiska hemvist och motivbild. Sakkunnigrapport inför rättegången i Oslo, 4 juni 20I2", i Det vita fältet II. Samtida forskning om högerextremism, specialnummer av Arkiv. Tidskrift för samhällsanalys, nr 2, s. I85-2I5.

DOI: http://dx.doi.org/IO.I3068/2000-6217.2.7

(C) Mattias Gardell/Arkiv förlag \& tidskrift 2013 (publicerad I6 september 2013)

Artikeln distribueras enligt en upphovsrättslicens från Creative Commons: Erkännande-Ickekommersiell-IngaBearbetningar 3.0 Unported, som medger fri ickekommersiell användning och spridning i oförändrat skick så länge källan anges. 
Arkiv. Tidskrift för samhällsanalys är en sakkunniggranskad vetenskaplig tidskrift för samhällsvetenskap och historia. Samtliga artiklar publiceras fritt tillgängliga på:

$$
\text { www.tidskriftenarkiv.se }
$$

(beständig länk, DOI: http://dx.doi.org/IO.I3068/2000-62I7)

Den här artikeln finns tillgänglig i följande format:

PDF \& HTML: via beständig länk, DOI: http://dx.doi.org/IO.I3068/2000-6217.2.7 EPUB: ingår i e-boksutgåva av numret, ISBN: 978 9I 7924254 I TRYCK: ingår i bokutgåva av numret, ISBN: 978 9I 79242558

Grafisk utformning och sidnumrering är identisk i pdf och tryck.

Samtliga artiklar i nr 2 (2013), Det vita fältet II. Samtida forskning om högerextremism, nås via beständig länk, DoI: http://dx.doi.org/I0.13068/2000-6217.2 redaktion för numret: Mats Deland, Paul Fuehrer och Fredrik Hertzberg

Arkiv. Tidskrift för sambällsanalys ISSN: 2000-62I7 (för elektronisk resurs) ISSN: 2000-6225 (för tryckta nummer)

ges ut av

Stiftelsen Arkiv för främjande och spridning av samhällsvetenskaplig och historisk forskning

genom

Arkiv förlag \& tidskrift

Box 1559 SE-22I OI Lund BESÖK: L Gråbrödersg 3 c, ipg TEL: O46-I3 3920

ARKIV FÖRLAG: arkiv@arkiv.nu·www.arkiv.nu TIDSKRIFTEN ARKIV: red@tidskriftenarkiv.se · www.tidskriftenarkiv.se

ANSVARIg UTGIVARE \& CHEFREDAKTÖR: Sven Hort AdMinistrativ Redaktör: David Lindberg ReDAKTörer: Paavo Bergman, Lisa Kings, Zhanna Kravchenko 


\section{DET VITA FÄLTET SPECIAL: RÄTTEGÅNGEN MOT BREIVIK}

\section{Anders Behring Breiviks politiska hemvist och motivbild. Sakkunnigrapport inför rättegången i Oslo, 4 juni $20 \mathrm{I} 2$}

MATTIAS GARDELL

\section{Prolog 187}

Anders Behring Breiviks politiska hemvist och motivbild. Sakkunnigrapport inför rättegången i Oslo, 4 juni 2012 I9I

Epilog 2II

Referenser 213 



\section{Prolog}

Den 22 juli 20II genomförde Anders Behring Breivik ett bombattentat mot regeringskvarteret i Oslo och en massaker på deltagare i det norska arbetarpartiets ungdomsförbunds sommarläger på Utøya. Sammanlagt mördades 77 människor, de flesta av dem ungdomar och skjutna på nära håll. Attackerna skrev in sig i en tradition av högerextremt våld riktat mot invandrare och vänstern, men omfattningen av de spektakulära attackerna var enastående. Inte sedan andra världskrigets slut hade Norge skakats av ett grövre politiskt motiverat våld. Eftersom det inte fanns någon modell för hur rättsväsendet skulle hantera ett fall som detta blev man tvungen att uppfinna vägen medan man gick. Var det korrekt att låta rättegången bli offentlig? Spelade man inte Breivik i händerna genom att ge honom möjligheten att använda rätten som politisk arena för att föra ut sitt budskap? Nu skulle visserligen inte Breiviks egna anföranden sändas på radio och teve, men han skulle ändå framträda inför journalister, anhöriga och intresserad allmänhet. Vore det inte bättre att dra för gardinerna och hålla rättegången bakom lyckta dörrar? När jag kalllades av rätten som sakkunnigt expertvittne, blev jag tvungen att ta ställning till dessa frågor. Min bedömning blev att det norska rättsväsendet handlat klokt. För det första kan inte en liberal demokratisk rättsordning hantera en attack mot den demokratiska ordningen med odemokratiska metoder utan att omvandla det som skulle försvaras till sin motsats. I en demokratisk rättsstat måste också en åtalad högerextrem mördare ges rätten att bli hörd. För det andra hade den norska allmänheten rätt att få veta, både för att det är från folket som makten i den ordning som attackerades sägs utgå och för att kunna ta sig igenom det trauma den 22 juli på flera sätt innebar. För det tredje var Breiviks åsikter influerade av 
en politisk miljö som fanns honom förutan och som knappast kommer att försvinna hur hårt vi än försöker blunda. Slutligen, för det fjärde, visar historien att ju tidigare man tystar en profet eller en revolutionär, desto större möjlighet att hen blir martyr.

Rättegången mot Breivik varade i tio veckor. Att den åtalade utfört de handlingar han anklagades för var klarlagt. Breivik hade erkänt, erkännandet stöttades av vittnesmål och teknisk bevisning, och utredningen visade att han under flera år planlagt och förberett sina dåd. Den stora frågan var således inte om den åtalade var skyldig, utan huruvida han i juridisk mening kunde anses tillräknelig eller inte. Mot varandra stod två psykiatriska utredningar. Torgeir Husby och Synne Sørheim ansåg att Breivik led av paranoid schizofreni, vilket kom till uttryck i hans bisarra vanföreställningar och storhetsvansinne, hans bruk av neologismer, att han tog sig rätt att döda och i hans oförmåga att sköta praktiska ting. Breivik var därför otillräknelig och skulle inte hållas juridiskt ansvarig för sina handlingar (Husby \& Sørheim 20I2). Terje Tørrissen och Agnar Aspaas kom fram till att Breivik var en narcissist, med bristande empatisk förmåga och en tendens att skylla samhället för hans tillkortakommanden, men inte psykotisk och därmed juridiskt tillräknelig (Tørrissen \& Aspaas 20I2). Till detta kom elva andra psykiatriska bedömningar, framlagda under rättegången, samt en som inte lades fram på grund av tystnadsplikt, men som ändå fick stor uppmärksamhet. Per Olav Næss föreslog att Breivik hade Aspergers syndrom (Omland m.fl. 2012), Ulrik Malt att han led av Tourettes syndrom (Børringbo \& Færaas 20I2), medan Randi Rosenqvist som ledde ett team som observerat Breivik i fängelset inte fann honom psykotisk eller schizofren (Rosenqvist 20II).

Fokuseringen på Breiviks mentala tillstånd medförde att de politiska motiv förövaren anfört hamnade i skymundan, inte bara i rätten utan också i det norska offentliga samtalet. Detta ändrades sedan sex sakkunniga kallats in för att utifrån sina respektive kunskapsområden granska Breiviks politiska filosofi och fascismens idéhistoria: Øyvind Strømmen som studerat högerextrema och islamofobiska bloggar och diskussionsforum på internet, Brynjar Lia, som forskar om politiskt motiverat våld vid Forsvarets forskningsinstitutt, Terje Emberland, forskare vid Holocaustsenteret och expert på nationalsocialismens historia, filosofen Lars Gule 
GARDELL | BREIVIKS POLITISKA HEMVIST OCH MOTIVBILD

som skrivit om politisk och religiös extremism, Tore Bjørgo som forskar om terrorism och rasistiskt våld vid Politihøgskolen och slutligen Mattias Gardell, religionshistoriker vid Uppsala universitet, som forskar i spänningsfältet mellan religion och politik och vars sakkunnigframställan i Breivikrättegången publiceras här. 



\title{
Anders Behring Breiviks politiska hemvist och motivbild. Sakkunnigrapport inför rättegången i Oslo, 4 juni 2012
}

\author{
SAKKUNNIG: MATTIAS GARDELL, \\ NATHAN SÖDERBLOM-PROFESSOR I JÄMFÖRANDE \\ RELIGIONSVETENSKAP VID UPPSALA UNIVERSITET
}

\section{Introduktion}

Mitt uppdrag är att förse rätten med ett kunskapsunderlag om den politiska miljö som Anders Behring Breivik inspirerats av. Det är en politisk miljö som legat i långkok de senaste tjugo åren och kan beskrivas som en "ny" extremhöger baserad på monokulturell nationalism, kulturrasism och antifeminism och som vunnit insteg i regionala och nationella parlament i Europa sedan de, mer eller mindre framgångsrikt, ersatt den antisemitiska agendan med en i dag mer solvent antimuslimsk dagordning.

Miljön är långt ifrån enhetlig och utgörs av en mångfald rörelser, partier, ideologer, debattörer, forum, bloggar, tankesmedjor, som kan ha sinsemellan motstridiga inställningar i olika sakfrågor, men som under senare år alltmer konvergerat i "motståndet” mot islam, muslimer, multikulturalism och relativiseringen av västerländska, kristna och/eller sekulära, värden.

Bland miljöns särdrag återfinns föreställningen att den ordning, kultur, nation, de vill slå vakt om är allvarligt hotad. Undergången har redan inletts, klockan står på fem i tolv och om inget omedelbart görs för att vända utvecklingen kommer världen såsom vi känner den oundvikligen gå under. Allvaret förstärks av den kontrafaktiska utsagan att det modiga fåtal som varnar allmänheten för islam, muslimer, massinvandring, multikulturalism och relativiseringen av de västerländska kristna 
och/eller sekulära värdena inte får komma till tals. Otaliga krönikor, ledare, artiklar, debattinlägg och böcker innehåller samma självmotsägande påstående att de åsikter författaren förmedlar och läsaren tar del av aldrig får framföras.

En av dem som i sina tal och texter flitigt upprepar detta påstående är Ayaan Hirsi Ali, antimuslimsk ideolog vid den kulturkonservativa tankesmedjan American Enterprise Institute. I ett vida återpublicerat tal hon höll i Berlin den Io maj 2012 förkunnade Hirsi Ali att "den man som dödade 77 människor i Norge för att han fruktade att Europa kommer att tas över av islam må ha citerat arbeten av dem som talar och skriver mot politisk islam i Europa och Amerika [däribland hon själv, som Breivik hänvisar till II gånger] men i sitt I 500-sidiga manifest skriver han inte att det var de som inspirerade honom att döda. Han säger uttryckligen att det var tystnadens advokater - genom att alla vägar att uttrycka hans åsikter var censurerade hade han inget annat val än att döda” (Hirsi Ali 20I2).

Utsagan är intressant av tre skäl. För det första för att hon godtar Breiviks syn på den 22 juli som en "marknadsföringsoperation" (Breivik 20II, s. I6) av annars censurerade åsikter. För det andra för att hon fäster uppmärksamheten vid det faktum att de åsikter Breivik framför inte nödvändigtvis är hans egna, utan inlånade från andra tänkare vars arbeten således publicerats snarare än censurerats. För det tredje tycks hon vilja anföra att de tänkare Breivik inspirerats av inte nödvändigtvis manar till våld, åtminstone inte explicit.

Det sistnämnda är ofta korrekt och jag ber rätten hålla det i minnet när jag lyfter fram de tanketraditioner och skribenter som Breivik i huvudsak hämtat sitt material från. Långt ifrån alla är lika radikala som Breivik, alla vill inte samma sak eller tycker likadant och även de ideologer vars politiska åskådning i stort sett överensstämmer med Breiviks undviker vanligen explicita maningar till våld - av orsaker jag snart kommer att klargöra.

Vad den 22 juli däremot demonstrerade var de yttersta konsekvenser som ligger inbäddade i det politiska talet. När Ayaan Hirsi Ali anför att västvärlden inte befinner sig i krig mot terror utan i "krig mot islam", att det inte finns moderata muslimer utan att problemet med muslimer 
är att de är muslimer - vilket medför att problemet endast kan lösas om muslimer upphör att vara muslimer eller upphör att finnas till - och att det är hög tid att "krossa fienden" som "infiltrerat väst" (Ayaan Hirsi Ali intervjuad i Wakefield 2007 och i Bakel 2007; Hirsi Ali 20IO), , är det inte helt förvånande att talet kan tolkas i termer av våldets politik. Vi återkommer till det.

\section{Kompendiet 2083}

Det material jag kommer att utgå ifrån är den text Breivik sände ut till utvalda mottagare i den antimuslimska miljön timmarna innan attackerna: 2083. A European Declaration of Independence. Huvudtiteln kommer från det år Breivik föreställer sig att slutmålet skall var uppnått: ett monokulturellt och patriarkalt kristet Europa utan förrädare, muslimer och vänsterintellektuella, och undertiteln är hämtad från en text med samma namn av den norske bloggaren Fjordman, Peder Nøstvold Jensen, som utgör en av Breiviks främsta inspirationskällor.

2083 är ett kompendium, det vill säga en sammanställning av texter, som Breivik till övervägande del inte skrivit själv utan lånat in från andra skribenter, med eller utan referens. Många av texterna är inkluderade i sin helhet, andra är kopierade i valda delar. I vissa fall har Breivik ersatt enskilda termer för att texterna skall stämma i sammanhanget, exempelvis genom att byta "amerikan" mot "europé" i en kulturkonservativ text som klagar över feminiseringen av den amerikanske mannen (Breivik 20II, s. 36-39, plagierat från Atkinson 2004). Även de texter vars författare inte angetts har kunnat spåras genom sökmotorer, varför vi med en viss exakthet kan fastställa varifrån Breivik hämtat sitt material.

Därmed går det också att fastställa vad kompendiet inte är. Vid sidan av vilda spekulationer om att Breivik egentligen skulle vara vänsterextremist eller styrd av Mossad eller frimurare (Madsen 20ıI; Aderet 20I2), har två vilseledande påståenden om Breiviks ideologiska hemvist vunnit viss spridning. Redan dagen efter dåden påstod Hans Rustad, initiativtagare till det norska antimuslimska forumet Document.no, där Breivik varit

I. Se även temakvällen "Kväll med Ayaan Hirsi Ali” på Axess Tv som sändes I3 april 20 Io (http://www.axess.se/Tv/webbtv.aspx?id=I775, hämtat I6 april 20ı0). 
en flitig deltagare, att "stora delar" av 2083 var kopierat från Unabomber Manifesto, publicerat 1995 av antimodernisten och teknologikritikern Ted Kaczynski, som utfört en serie om I6 bombattentat mot amerikanska universitet och flygbolag (Rustad 20II). Johan Lundberg, chefredaktör för den kulturkonservativa tidskriften Axess, omvandlade uppgiften till "den ideologiska kärnan" i Breiviks ideologi (Lundberg 20II), vilket tacksamt togs emot av Sverigedemokraterna, ett av Breivik hyllat antimuslimskt parti som tagit säte i riksdagen (se t.ex. Ekeroth 20II). Stämmer påståendet? Nej. Tre (3) av I 5I6 sidor är tagna från Unabomber Manifesto, ur ett avsnitt där Kaczynski angriper "vänstern", en term Breivik ersatt med "multikulturalism". Resten kommer från annat håll. Den andra vilseledande uppgiften gör gällande att Breivik är en al-Qaidakopia. Den svenske "terrorismexperten" Magnus Ranstorp uppgav att kompendiet 2083 var "en klipp-och-klistra-bild av ett jihadistiskt manifest", där "Breivik kopierar modellen för gör-det-själv-terrorismkampanjer och motståndstemat från al-Qaidainspirerade källor” (citerad i Boston 20II). Att Ranstorp inte underbygger påståendet genom att hänvisa till vilka delar Breivik kopierat från vilka jihadistiska manifest är ingen tillfällighet, ty Breivik har hämtat sitt material från andra källor - inklusive en längre text publicerad på Ranstorps eget forskningscentrum som Breivik plagierat i sin helhet (Kohlmann 2006; Breivik 20II, s. 264-282). ${ }^{2}$

\section{Breiviks politiska influenser}

Ser vi till Breiviks huvudsakliga politiska influenser kan tre tongivande idéströmningar identifieras: islamofobi, kulturkonservativ nationalism och antifeminism. Till detta kommer element ur vitmaktideologi, högerkristen teologi och nationalromantiska tempelriddartraditioner, all genomsyrat

2. Al-Qaida nämns 54 gånger, i nästan samtliga fall som fiende. Vid ett tillfälle skriver Breivik att den antimuslimska nationaliströrelsen bör lära sig av al-Qaida och arbeta i tandem med mer moderata kulturnationalistiska krafter i stället för att fördöma dem (20II, s. I262), vid ett tillfälle sägs al-Qaida vara en framgångsrik militant organisation (20II, s. I473). Vid ytterligare ett tillfälle får läsaren råd att läsa al-Qaidas manual, men hänvisningen är inte till någon jihadistsida utan till http://www.disastercenter.com, en myndighetsrelaterad hemsida som handlar om olika typer av främst naturkatastrofer i Förenta staterna och hur man skyddar sig mot dem. 
av ett utpräglat romantiskt manligt krigarideal. Jag kommer att gå igenom de bärande tanketraditionerna var och en för sig. Framställningen kommer att visa att de bisarra vanföreställningar Torgeir Husby och Synne Sørheim pekade på då de föreslog att Breivik led av paranoid schizofreni inte är unika för den åtalade, utan vanligt förekommande i den politiska miljö han inspirerats av. Detsamma gäller det Husby och Sørheim felaktigt trodde var Breiviks neologismer, som "kulturmarxist", "självmordshumanist", "nationaldarwinist" och "rättfärdighetsriddare". Samtliga termer har varit i omlopp länge. De tre första i kulturkonservativa och högerextrema kretsar och den sista är hämtad från tempelriddartraditionen. Låt mig genast inskjuta att jag i övrigt inte tar ställning till de rättspsykiatriska utredningar som redovisats. Jag är inte psykiatriker utan historiker. Föreställningen att "islam" och "väst" är väsensskilda och inkompatibla monoliter som befunnit sig i konflikt under I 300 år är förvisso en vanföreställning, men den har en lång idéhistoria och omfattas inte enbart av Breivik. Skall de alla tvångsvårdas får ni bygga en gigantisk vårdanläggning. Som historiker kan jag konstatera att vanföreställningar och politik inte alltid varit åtskilda i den västerländska historien: föreställningar om blått blod, den vita rasens inherenta överlägsenhet, presidenter som tror sig kallade av Gud och civilisationens krig mot ondska. Betänk föreställningen om en judisk världskonspiration som vann spridning under 1900-talets första årtionden och dess förödande politiska konsekvenser.

Kompendiets sammanställning är Breiviks egen, men världsbilden återspeglar en tendens som växt fram ur den vidare kulturkonservativa antimuslimska miljön under senare år. Den kan identifieras som fascistisk enligt den brittiske statsvetaren Roger Griffins definition av fascism som "en revolutionär form av nationalism, som vill åstadkomma en politisk, social och etisk revolution som skall sammansvetsa 'folket' till en dynamisk nationell gemenskap under en ny elit, uppfylld av heroiska värderingar. Nyckelföreställningen i projektet är att endast en populistisk, klassöverskridande nationell pånyttfödelse kan vända dekadansens tidvattensvåg” (Griffin 1993, s. ix). I Breiviks version centreras projektet kring visionen om ett pånyttfött Europa som renat genom krigets stålbad reser sig ur förnedringen för att återta sin forna storhet. Jag åter- 
kommer till detta efter genomgången av de tanketraditioner som Breivik hämtat näring ur.

I. Islamofobi. Islamofobi är ingen "fobi" i psykiatrisk mening, utan används precis som i termerna "xenofobi" och "homofobi" i överförd bemärkelse om historiskt, socialt och politiskt reproducerade aversioner mot och diskriminering av bestämda kategorier människor, i detta fall "muslimer", framställda som ett föreställt och negativt laddat kollektiv som tillskrivs vissa bestämda egenskaper som alla muslimer anses dela oberoende av tid och rum, vilket möjliggör talet om "hur muslimer är". ${ }^{3}$ Det essentialistiska skillnadstänkande som framställer "muslimer" som en från den universella människan särskild sort har långa idéhistoriska rötter. Den återkom i sin nuvarande tappning efter kalla krigets slut och slog igenom på allvar under kriget mot terrorismen. För Breivik är islam västvärldens ärkefiende. Som extern fiende omnämns islam och muslim(er) 7 I 55 gånger (islam 3 466, muslim 3 689) i kompendiets I 516 sidor. Breivik lutar sig här mot en rad antimuslimska skribenter som ofta hänvisar till varandra för att underbygga sina påståenden om hotet från islam och muslimer, inklusive: Serge Trifkovic (2I gånger), som bland annat skrivit Defeating Jihad (2006) och var rådgivare åt krigsförbrytaren Radovan Karadžić i Republika Srpska under det bosniska inbördeskriget; Bruce Bawer (I2 gånger), författare av While Europe Slept (2006) och The New Quislings (20I2) där han stämplar liberaler och vänsterintellektuella som inte delar hans fiendebild som landsförrädare samtidigt som han klagar över att vara förföljd bara för att Breivik citerat honom; Andrew G. Bostom (23 gånger), en amerikansk läkare som utan att kunna arabiska publicerar exegetiska analyser av islamiska urkunder och funnit att erövringskrig och judehat är inneboende drag hos muslimer; författaren Robert Spencer (46 gånger), som driver bloggen Jihad Watch, bjöds till Almedalen av Sverigedemokraterna och som tillsammans med Pamela Geller bildade organisationen Stop Islamization of America; Gisèle Littman, som under pseudonymen Bat Ye'or (25 gånger) skrivit det inflytelserika konspirationsteoretiska verket Eurabia (2005); och inte minst den norske bloggaren Fjordman, Peder Nøstvold

3. För en begreppsutredning, se Gardell (2OII). 
Jensen, som utgjort Breiviks enskilt viktigaste influens (39 hela texter, III referenser).

Genom att mobilisera dessa antimuslimska skribenter frammanar Breivik en manikeisk bild av en evig strid mellan ljusets och mörkrets krafter som nu går mot sin apokalyptiska kulmen. I I 400 år har "islam”, skildrad som en aktör med sinister agens, sökt utrota Europa, frihetens utpost i världen. Vid två tidigare tillfällen har muslimska invasioner stoppats i sista stund, vid slaget i Poitiers 732 och vid Wiens portar I683. Den tredje och avgörande striden är nu i full gång. Denna gång har "islam" i hemlighet kontrakterat europeiska landsförrädare - politiker, vänsterintellektuella och feminister - som låtit fienden inrätta avelskolonier i Europas städer. Eftersom muslimer sägs vara av naturen väsensskilda från européer förblir en muslim som fötts i Europa "muslim" och inte norrman eller europé. Därmed utgör muslimernas ständiga barnafödande en demografisk krigföring som kommer att militariseras så snart de blivit tillräckligt många. Vi befinner oss därför vid en kritisk punkt i den västerländska historien. "Våra anfäder, bättre män och kvinnor än vad vi är, höll islam stången i mer än ett årtusende, de offrade sitt blod för kontinenten. Genom att göra det räddade de inte endast hjärtat av Europa och därmed den västerländska civilisationen, utan sannolikt också hela världen från ohämmad islamisk dominans. Det som står på spel nu är inte mindre än vad det var då, troligen ännu mer" (Breivik 20II, s. 716, taget från Fjordman 2008a). Som tur är har de ondskefulla planerna avslöjats sedan antimuslimska skribenter funnit efterlämnade protokoll från den ockulta konspirationens hemliga möten i schweiziska villor eller Barcelonaprocessens konferenshotell, vilket gett de antimuslimska trupperna en tidsfrist att mobilisera motstånd. Här finns inte tid att detaljerat redogöra för Eurabienlitteraturens olika varianter, men dess beroende av äldre antisemitiska konspirationsteorier är uppenbar och den kommer komplett med egna motsvarigheter till "Sions vises protokoll" (se t.ex. Besson 2005; Ye'or 2005; 20II; Kozak 2010; Fjordman 2008b).

2. Kulturkonservatism. Här inkorporerar Breivik, vanligen utan källanvisning, texter av främst amerikanska konservativa skribenter, inklusive: William S. Lind, chef för Center for Cultural Conservatism; T. Kenneth 
Cribb Jr, rektor för den traditionellt konservativa Intercollegiate Studies Institute och tidigare rådgivare åt Ronald Reagan; Gerald L. Atkinson, pensionerad befälhavare vid US Naval Academy och redaktör för de kulturkonservativa (nät)tidskrifterna Eternal Vigilance och New Totalitarianism; och Raymond V. Raehn, grundare av den till World AntiCommunist League anknytna US Global Strategy Council och medlem i den vitnationalistiska organisationen Council of Conservative Citizens.

Genom dessa skribenter fokuserar Breivik udden mot den inre fienden, "kulturmarxister" och "multikulturalister" som sammanlagt omnämns 2 30I gånger i kompendiet (ord bildade på Marx, I 137; ord bildade på multicultural, I I64). Breivik beklagar att västvärldens ledare inte tog kriget mot kommunismen på allvar: "Om vi hade avrättat säg IO० 000 marxistiska intellektuella i Västeuropa efter det andra världskriget och förbjudit varje form av marxistiskt tänkande hade vi kunnat förhindra uppkomsten av den anti-europeiska hatideologin känd som multikulturalism” (Breivik 20II, s. I277). Genom de konservativa skribenter han plagierar ondgör sig Breivik över intellektuella som Sigmund Freud, Karl Marx, Antonio Gramsci, Theodor W. Adorno, Wilhelm Reich, Herbert Marcuse, Georg Lukács, Michel Foucault, Jacques Derrida och Edward Said, och har ett särskilt horn i sidan till postkoloniala studier, poststrukturalism och queerteori. Enligt Breivik har vänsterintellektuella kulturmarxister systematiskt förnekat det inneboende värdet i vita, kristna, heterosexuella europeiska män och försökt vända den traditionella sociala ordningen på huvudet $\mathrm{i}$ tron att muslimer, minoriteter, homosexuella och feminister skulle bana väg för en revolution baserad på den naturvidriga idén om jämlikhet. Sedan de inrättat oinskränkt makt på universiteten har kulturmarxisterna systematiskt utestängt och förhånat de kulturkonservativa nationalistiska män som vågat protestera för att därmed undanröja den enda kraft som kan stå emot den pågående islamiseringen av Europa. Lösningen ligger förborgad i den "vanliga människans sunda förnuft" (Breivik 20II, s. 36, taget från McDonald 2004), varför det är avgörande att "nå ut med sanningen" innan Europa inom ett par årtionden dukar under. Kulturmarxister måste bannlysas från universitet och kulturrelativism och mångfald ersättas med en historieskrivning som 
återupprättar värdet av Europa, den västerländska kanon och den traditionella ordningen. "Om vi, det västeuropeiska motståndet, misslyckas eller blir uppgivna kommer Västeuropa falla och med det din och dina barns frihet" (Breivik 20II, s. I3).

3. Antifeminism. Feminister utgör den andra kategorin inre fiender (218 gånger). Här återkommer Breivik till Fjordman och kulturkonservativa amerikaner som mobiliseras jämte konservativa kvinnliga skribenter som: Christina Hoff Sommers, liksom Ayaan Hirsi Ali verksam vid American Enterprise Institute; Phyllis Chesler som i The Death of Feminism (2005) anklagar feminister för att ha blivit promuslimska multikulturalister och som är en flitig skribent i antimuslimska FrontPage Magazine; och Melanie Phillips, den brittiska journalist som vandrat från vänster till höger med attacker mot "homolobbyn" och multikulturalismen, och som skrivit den konspirationsteoretiska Londonistan (2006) om hur korrupta politiker inbjudit islamiseringen av England.

För Breivik och de skribenter han lånar texter av spelar feminismen en nyckelroll i en dystopisk berättelse om västvärldens undergång. Det började redan med den tidiga kvinnosaksrörelsen under sent I80o-tal-tidigt I900-tal, med dess sociala reformagenda, krav på kvinnlig rösträtt, jämlikhetsideal, krigsmotstånd och antikolonialism, vilket Breivik ser som förfallets inledning, början på den europeiska kulturens feminisering. Under det andra världskriget och den tidiga efterkrigstiden stabiliserades samhället och könsordningen normaliserades. Breivik är född 1979, men drömmer sig - genom de amerikanska kulturkonservativa skribenter han använder sig av - tillbaka till ett tänkt I950-tal som den ideala tidsåldern, då män var män, kvinnor var kvinnor, barnen var väluppfostrade och då det varken fanns kriminalitet eller muslimer i våra länder. ”De flesta män behandlade kvinnor som damer och de flesta damer ägnade sin tid åt att sköta hemmet, uppfostra barnen och bistå samhället genom välgörenhetsarbete. Barnen växte upp i tvåföräldershushåll och modern fanns där för att möta barnet när han kom från skolan” (Breivik 20II, s. 20, plagierat från Lind 2004). Allt skulle förstöras under den andra vågen av feminism, som under 1960-talet vände sig mot naturens ordning. "Den patriarkala samhällsstrukturen skulle ersättas med matriarkat, tron att 
män och kvinnor är olika och bör ha skilda roller skulle ersättas med androgynitet; och tron att heterosexualitet är normalt skulle ersättas med tron att homosexualitet är lika normalt" (Breivik 20II, s. 24, taget från Raehn 2004). Breivik ser feminismen som fullständigt förödande. Feminister underblåser multikulturalism, de ömmar för flyktingar, för samhällets olycksbarn och de har feminiserat västerländska män, som vet hur man byter blöjor men inte hur man slåss. "Den kanske viktigaste insikten är att så många av våra kvinnor är förrädare", skriver Breivik. "Det är måhända inte ett genomtänkt förräderi, eftersom våra kvinnor endast tänker och handlar i enlighet med hur naturen skapat dem.” Breivik vidgår att det låter sexistiskt, "men naturen i sig är sexistisk och man kan inte bryta mot primära naturlagar" (Breivik 20II, s. I358). Naturens lagar är hårda och så är krigets. "Varje kvinnlig förrädare är någons dotter, någons syster eller mor", konstaterar Breivik. "Det är väsentligt att förstå att cirka 60-70 procent av alla kulturmarxister eller självmordshumanister är kvinnor ... Att vara en rättfärdighetens riddare innebär att döda våra mål ... Om du är ovillig eller oförmögen att döda kvinnor på grund av ridderlighetsprinciper skall du hålla dig borta från väpnade motståndsrörelser" (Breivik 20II, s. 942).

Att återupprätta patriarkatet blir enligt Breivik hörnstenen i den Nya Ordning som skall etableras sedan förrädarna avrättats och muslimerna fördrivits. "Så fort kvinnor åter kommer att skolas genom rättfärdiga institutioner och växa upp i starka och enade kärnfamiljer ledda av en självsäker patriark kommer hon att veta sin plats i samhället och vidare regleringar kommer att vara överflödiga" (Breivik 20II, s. II48). För detta behöver, enligt Breivik, ett antal "strategiska lagar" införas. För det första måste fadern garanteras vårdnaden av barnen. Det kommer att få kvinnorna att stanna kvar. För det andra måste skilsmässa utan laga skäl (no-fault divorce) åter förbjudas och för det tredje måste förbudet mot disciplinär aga hävas. Därmed säkras den traditionella familjen genom vilken naturens könade ordning kan prägla barnen: pojkar lär sig bli självsäkra, aggressiva, dominanta och produktiva, medan kvinnorna lär sig bli milda, omhändertagande, emotionella och reproduktiva. De lär sig att män förväntas fatta besluten och att kvinnor förväntas lyda (Breivik 20II, s. II5I). 
4. Vitmaktideologi. I likhet med den miljö han kommer ur tar Breivik explicit avstånd från rasism, nazism och antisemitism, samtidigt som bärande element ur dessa traditioner bibehålles. I rasfrågan är Breivik ambivalent. Han skriver att han först "tvekade att inkludera orden ras, vit eller etnicitet" eftersom "jag ... övertygade mig själv att jag primärt var mot islam" och "endast skulle komplicera kampen" om "[jag] skrev om hudfärg", inte minst då "européer identifierar sig som européer och inte som vita". Breivik försökte därför "ersätta termerna [ras och vit] med orden kultur, infödd europé eller etnisk grupp", men fann att det "i många fall helt enkelt var omöjligt" (Breivik 20II, s. 398). Sålunda inkluderade han långa utdrag ur From Titans to Lemmings. The Suicide of the White Race, en rasistisk kampskrift publicerad av British National Party (Reconquista 2009; Breivik 20II, s. 398-407). I linje med vitmaktideologer oroar sig Breivik för att den vita rasen och särskilt den nordiska genotypen är utrotningshotad, varför han infogar långa rashygieniska avsnitt om hur den nordiska "ursprungsbefolkningens" överlevnad skall säkras genom invandringsförbud, åtskilda bostadsområden för den lågavlönade tjänsteklass från tredje världen som på korttidskontrakt ändå skall städa våra hem, statliga bidrag till renrasiga flerbarnsfamiljer, genbanker och industriellt surrogatmödraskap (Breivik 20II, s. II9O-II98). Breivik är förtrogen med vitmaktlektyr och bekymrar sig för att odinister (rasistiska hedningar) och nationalsocialister skall ställa sig utanför motståndsrörelsen för att de inte accepterar den antimuslimska kulturkonservativa miljöns kristna respektive proisraeliska sidor. Han uppmanar därför odinister och nazister att koncentrera sig på den överordnade kampen mot kulturmarxister och muslimer.

Breivik ser den israeliska högern som en naturlig allierad i kampen mot islam, men trots hans förmenta filosemitism finns en tydlig antisemitisk dimension i kompendiet. Breivik menar att den tyska nazismen ämnade åtgärda dåtidens problem och att det i dagens Europa inte finns något judiskt problem - förutom i Frankrike och Storbritannien som hyser 800 ooo av kontinentens en miljon judar. Detta kontrasterar han med situationen i Förenta staterna som med sina sex miljoner judar enligt Breivik har ett "avsevärt judiskt problem" (Breivik 20II, s. II67). Breiviks filosemitism är uppenbart villkorad. Goda judar skall idealt 
befinna sig i Israel och ägna sig åt att expandera landet på palestiniers bekostnad och där vill Breivik gärna hjälpa till. Judar som envisas med att stanna kvar i Europa måste ansluta sig till den antimuslimska kampen. "Neutralitet i denna fråga är inte ett alternativ" (Breivik 20II, s. I374). Judar som inte förstår att uppföra sig enligt hans plan klassificeras som förrädare. När den nationalistiska revolutionen segrat skall Europa omvandlas till en monokulturellt kristen kontinent och då finns ingen plats för judar längre.

Det element Breivik hämtar från modern vitmaktideologi som är av störst vikt för denna rättegång är det ledarlösa motståndets strategi som uppstod i Förenta staterna mot slutet av 1970-talet-början av I980-talet, när ledande vita rasister som Louis Beam, David Lane, Robert Matthews, James Mason, Ben Klassen och William Pierce började inse att slaget om den federala makten var förlorad. Rasens fiender sades kontrollera Vita huset och Kongressen genom en hemlig skuggregering, ofta benämnd ZOG, den sionistiska ockupationsregimen. Då polis och säkerhetstjänst inte längre kunde betraktas som allierade vore det riskabelt för vita rasister att enbart organisera sig i traditionella, medlemsbaserade rörelser som kunde övervakas och infiltreras. Motståndet skulle i stället byggas på en bodelning mellan en öppen gren av politiker, propagandacentrum och ideologer som skulle hålla sig inom lagens ramar och en underjordisk gren av väpnade celler och enskilda mördare (lone wolf assassins) som själva ansvarade för att finansiera, planera och genomföra operationer, utan order uppifrån (Gardell 2003; Beam 1992). I Förenta staterna kom strategiskiftet till uttryck i en rad ariska gerillagrupper, rasistiska seriemördare och bombattentat, däribland bomben mot det federala kontorskomplexet i Oklahoma City 1995, som Breivik ser som exemplarisk. Med vitmaktmiljöns globalisering under 1990-talet - med internet och vitmaktmusik som viktiga drivkrafter - kom strategin att anammas av grupperingar i Europa, inklusive Sverige, där den bland andra inspirerade Lasermannen och under senare tid Lasermannen II (Peter Mangs) och Den nationalsocialistiska underjorden i Tyskland som Breivik direkt refererade till i rätten som hjältemodiga bröder i kampen. Av kompendiet är det uppenbart att Breivik har anammat det ledarlösa motståndets strategi. Den tempelriddarorden Breivik utger sig för att tillhöra är inte en organi- 
sation utan en "decentraliserad plattform för självorganiserad handling" (Breivik 20II, s. 828), och han varnar för att upprepa det misstag som begicks av Det tysta brödraskapet (Brüder Schweigen, eller The Order) - en arisk gerillagrupp som opererade i nordvästra USA i början av I980talet och som har kultstatus i vitmaktmiljön. Brödraskapet växte till ett hundratal medlemmar och kunde spåras för att de stod i kontakt med varandra. Idealt, menar Breivik, skulle de ha delat upp sig i 50-Ioo celler och avbrutit all kontakt mellan sig (Breivik 20II, s. 845). Breivik betonar att varje "patriot" som väljer riddarens väg - "en väg av styrka och ära, mod och martyrskap" - "av praktiska skäl måste ge upp eventuella medlemskap i [öppna antimuslimska] organisationer" - precis som han själv gjorde - för att inte deras våldshandlingar skall skada partierna (Breivik 20II, s. 83I). Krigaren blir en del i ett "nätverk av celler, spridda runt om i Europa, som fungerar utan centralkommando" och "utan att avvakta order uppifrån. Din skyldighet som rättfärdighetsriddare/cellkommendant är att agera på eget initiativ" (Breivik 20II, s. 837). Som en service till det tänkta underjordiska nätverk av kristna riddare Breivik talar till förmedlar han information om hur man skaffar vapen, hur man bygger bomber och hur man producerar kemiska och biologiska stridsvapen (som mjältbrandsbakterier) som Breivik funnit på gör-det-själv-hemsidor i cyberspace, som exempelvis Douchermann's Chemistry Page. ${ }^{4}$

5. Element ur högerkristen teologi. Breivik ser sig som "IOO \% kristen" men inte "överdrivet religiös" och betonar mer det kristna kulturarvet än någon personlig relation till Gud. Han ser dagens kyrka som en del av problemet. Den institution som skulle vara moralens och traditionens väktare har förfallit till prästvigning av kvinnor och homosexuella, förslappad kyskhet, godkännande av abort och religionsdialog med muslimer (Breivik 20II, s. II38, I222). Breivik söker sig i stället över Atlanten till högerkristna predikanter som Joseph Francis Farah och Michael Bradley, som är populära i milisrörelsen och bland Tea Party-aktivister och som han funnit via forum som World Net Daily. "Gud vill inte att du skall vara en mes [pyse, wimp] och han förväntar sig att var och en

4. Douchermann's Chemistry and Pyrotechnics Tutorials and other information, finns på http://williestop.tripod.com, se även http://www.survivalblog.com. 
av oss lär sig hur man krigar mot varje fiende som kommer i vår väg”, skriver Breivik (20II, s. I333), 5 och lyfter fram Lukas 22:36 (här i I9I7 års översättning): "den som icke har något svärd, han sälje sin mantel och köpe sig ett sådant". Efter segern skall Europa bli hundraprocentigt kristet, men ateister skall ha samma rättigheter förutsatt att de är ateister på rätt sätt, det vill säga utfäster sig att vara kulturellt kristna. De olika kyrkorna skall förena sig under en hårdför "korsfararpåve" och en kristen kongress med religiösa, militära och politiska ledare skall sammankallas för att utarbeta Europas kristna och kulturella plattform. Kyrkan skall ha vikta platser i parlamentet och agera rådgivare åt regeringen, men inte ha vetorätt. Kristendom kommer att vara kontinentens enda officiella religion och kyrkan skall ges ett bestämmande inflytande över skolschema och myndighetsutövning.

6. Tempelriddartraditionen. Breivik inkluderar långa utdrag ur den franske abboten Bernhard av Clairvaux regelverk En hyllning till den nya riddarordern som skrevs för den ursprungliga Tempelherreorden ca II 32. Breivik är inte den förste att tala om en återuppstånden tempelriddarorden. Tempelriddarmystik och jakten på den heliga graalen har sedan I70o-talet varit en integrerad del i den västerländska esoteriska traditionen och med Sir Walter Scotts nationalromantiska epos Ivanhoe (I8I9) gjorde tempelriddarna insteg i den folkliga föreställningsvärlden. Under I8oo-talet uppstod en serie tempelriddarordnar, vanligen som en del av nykterhetsrörelsen och med frimurarliknande orientering. Dagens tempelriddare utgörs vanligen av distingerade gentlemän, vilka chockades då Breivik genomförde terrorattentat i deras namn. Utanför den högborgerligt kristna mystikens värld har tempelriddarna emellertid också attraherat vita rasister. Nationalromantiska föreställningar vävda kring tempelriddarna var en inspirationskälla för de kristna riddarna i Ku Klux Klan och i den tyska völkisch-miljön uppstod ett antal arisk-kristna hemliga

5. Taget från Battle Verses of the Bible, från webbplatsen Bible-Knowledge.com (http:// www.bible-knowledge.com/battle-verses-of-the-bible, hämtat 3I oktober 20II). Återfinns idag (26 februari 20I3) på sidan God Will Give You His Strength, Boldness, and Courage to Walk With His Anointing, från samma webbplats (http://www.bible-knowledge.com/ god-will-give-you-what-you-need-to-walk-with-his-anointing). 
sällskap, som exempelvis Ordo Novi Templi, grundat 1907 av Jörg Lanz von Liebenfels, vars ariosofi (läran om den ariska rasens gudomlighet) skulle bäras vidare in i Tredje riket genom bland andra Reichsführer-SS Heinrich Himmler för vilken (de föreställt ariska) tempelriddarna stod modell för SS och dess ockulta uppdrag (Goodrick-Clarke I992).

Att självutnämnda krigare i dagens militant antimuslimska miljö skulle inspireras av tempelriddarna är knappast förvånande. Breivik är inte ensam om sina romantiserade korsriddardrömmar och var heller inte först. English Defence League och den vidare kontrajihadistiska miljön hyllar tempelriddarna och andra korsfarare som historiska förebilder att modellera dagens kamp på. Breivik skriver ingående om den tempelriddarorden han påstår sig tillhöra, dess befälsordning, initiationsriter, heraldik, medaljer, begravningsceremonier, militära utrustning och träning, samt dess gudagivna uppdrag att försvara det kristna fäderneslandet, utrota marxismen och rena Europa från islam (Breivik 20II, s. 842-918, 926-976, I074-II23). I likhet med Ancient Order of the Templar Knights, en antimuslimsk och antikommunistisk riddarorden som företräds av Paul Ray, en av EDL:s grundare och som efter interna strider i EDL:s ledning bosatte sig på Malta, är Breiviks orden inte en organisation i traditionell bemärkelse utan en idé, en vision med performativ funktion, som använder sig av tempelriddarsymbolik och ikonografi för att skapa den stämning, inställning och riktning han uppfattar nödvändig. Av samma anledning är miljön full med referenser till Karl Martell, den frankiske furste som besegrade de iberiska morerna i slaget vid Poitiers 732 och Johan III Sobieski, den polske furste som besegrade ottomanerna vid Wiens portar I683. Budskapet är att det kristna Europa åter står inför samma ärkefiende varför de slumrande krigarinstinkter som ligger förborgade i den vite kristne mannens natur måste väckas till liv för att producera hjältar av samma kaliber på det att muslimerna och förrädarna skall kunna tillintetgöras. I en text från 2009 skriver Fjordman att det är hög tid för en ny Karl Martell att stiga fram för att leda striden mot islam, en maning Breivik svarade på. I kompendiet hänvisar Breivik till Martell 55 gånger och en av de utmärkelser hans tempelriddare kan föräras är Karl Martells och Johan III Sobieskis medalj för exceptionella insatser mot multikulturalism och islamiseringen av Europa. I slutet av kompendiet har Breivik bifogat 
marknadsföringsbilder på sig själv. På den bild där han framträder i tempelriddaruniform bär han den medaljen på bröstet. Breiviks berättelse om tempelriddarorden bör således inte ses som en beskrivning av en befintlig organisation utan som en performativ utsaga som avser att skapa det den hänvisar till: ett avantgarde av heroiska korsfarare som banar väg för en paneuropeisk och nationalistisk revolution. Visionen är distinkt fascistisk. Udden är riktad mot den inre fienden - kulturmarxister, multikulturalister och feminister - vars strävan efter jämlikhet och alla människors lika värde hotar tillintetgöra kristendomen och de europeiska kulturerna och öppnar för en islamisk kolonisering. Breivik betonar att islamiseringen av Europa endast är en "sekundär infektion": "Västeuropa har blivit svagt och dekadent och kommer att bli fullständigt kulturellt utrotat om vi inte lyckas förverkliga en andra europeisk renässans och hela den skada som åstadkommits" (Breivik 20II, s. 1354). ${ }^{6}$

\section{Kontrajihadister}

Breivik hade omfattande kontakter i England. Han var länkad till 600 medlemmar i English Defence League via Facebook och sände sitt manifest till 250 utvalda mottagare i England, varav majoriteten var medlemmar i EDL eller British National Party. Bakom EDL står mångmiljonären

6. Breivik skriver (i originalets engelska):

The PCCTS, Knights Templar is a European indigenous rights movement and a Crusader movement (anti-Jihad movement), a part of the pan-European and national resistance movement. In a way it is a conservative revolutionary movement.

By propagating and defending Christendom we simply mean that we want to halt the cultural Marxist/multiculturalist attacks and systematic deconstruction on our Christian cultures and the Church itself and to reverse the de-Christianisation of Europe. The biggest threat to Europe is the cultural Marxist/multiculturalist political doctrine of "extreme egalitarian emotionalism". This type of political stance involves destroying Christendom, the Church, our European cultures and identities and opening up our borders to Islamic colonisation. The Islamisation of Europe is merely a "secondary infection". Western Europe has grown weak and decadent and will be completely annihilated culturally unless we succeed to implement a second European renaissance and reverse the damage done (Breivik 20II, s. I354). 
Alan Lake, som våren 2009 kopplade samman fotbollshuliganer, skinnskallar, högerextremister och "patrioter" i en antimuslimsk kamporganisation som skulle ta striden till gatorna. EDL har utmärkt sig för aggressiva demonstrationer genom bostadsområden med många muslimska invånare - inte helt olikt den tidiga $\mathrm{Ku}$ Klux Klans rituella marscher genom svarta bostadsområden. Fjordman hälsade EDL med entusiasm som "modiga män och kvinnor som efter år av förnedring och degradering slutligen har tröttnat på att behöva bevittna hur ondskefulla grupper och organisationer från andra delar av välden tillåtits kolonisera deras land". "De representerar potential och hopp. Därför stöder jag EDL:s kamp och därför bör också du göra det” (Fjordman 20II). I september 2009 bjöds Lake till Sverige av Kent Ekeroth, internationell talesperson för Sverigedemokraterna, för ett seminarium om kampen mot islamiseringen och Ekeroth lade upp Lakes rekommendationer om hur kampen skall föras på Youtube. ${ }^{7}$ Kopplade till paraplynätverket Stop Islamisation of Europe uppstod liknande "defence leagues" i Danmark, Finland, Frankrike, Norge, Polen, Rumänien, Ryssland, Tyskland och Sverige. Sommaren 2010 bildades Swedish Defence League genom stöd från bröderna Ekeroths antiislamiseringskampanj och under senhösten samma år bildades Norwegian Defence League. Oavsett om Breivik var medlem i NDL eller inte - här går uppgifterna isär och Breivik bör i linje med det ledarlösa motståndets strategi hur som helst förneka det - har både SDL och NDL på grund av dysfunktionellt ledarskap, interna stridigheter och (åtminstone i Sverige) konflikter med mer klassiskt orienterade nationalsocialistiska kampgrupper, inte kommit i närheten av att matcha EDL:s betydelse. Men ambitionen finns.

Alan Lake driver 4 Freedoms Community som är ett av de webbforum som knyter samman ideologer, partier och kampgrupper i den kontrajihadistiska miljö som Breivik imponerades av. Lake ledde den brittiska grenen av Center for Vigilant Freedom (tidigare 9Io Group), grundad av amerikanen Edward S. May - som driver bloggarna Gates of Vienna och Brussels Journal, som Fjordman publicerar sig i och som Breivik regelbundet läste. År 2007 föreslog May att det antimuslimska samarbetet

7. "Seminar about Islamization, Speaker: Alan Lake", upplagd av Kent Ekeroth (http:// www.youtube.com/watch?v=GMzFFm2V4QE, hämtat I3 augusti 20II). 
borde förtätas och ett första möte med speciellt inbjudna nyckelpersoner runt om i Europa sammankallades i Köpenhamn, med Anders Gravers Pedersen, ledare för Stop Islamiseringen af Danmark, som värd. Från Norge deltog Peder Nøstvold Jensen och från Sverige SD:s Ted Ekeroth, bloggaren Fröken Sverige (med bloggen I mitt Sverige) och "Reinhard" från Forum mot islamisering, som alla är kopplade till Sverigedemokraterna. Därefter har årliga antimuslimska "top summits" hållits i Bryssel 2007, Wien 2008, Köpenhamn 2009, Zürich 2010 och Strasbourg 20II. Vid toppmötena varvades landrapporter med föreläsningar från antimuslimska stjärnor som Robert Spencer, Pamela Geller, Serge Trifkovic och Bat Ye'or och arbetsgrupper som diskuterade juridik, strategier och visioner. Kampen mot islam skulle föras på många nivåer: genom lagförslag (förbjud slöjor, minareter, moskéer), gatukamp (efter EDL:s recept), sociala medier (där man redan var starka), direkt aktion (mot moskébyggen och muslimska centrum) och parlamenten (ett av Brysselmötets seminarier hölls i EU-parlamentet, ett i det flamländska parlamentet och toppmötena har gästats av parlamentsledamöter från olika länder). Enligt May är idén inte "att få alla att gå med i samma organisation: Gud förbjude!" I stället förespråkas ett ledarlöst motstånd i ett "nätverk av nätverk" utan "kommandokedja". Det "finns ingen partilinje. Ingen som kontrollerar vad som sker. Enhet skapas genom en gemensam målsättning. Allt annat är detaljer". "Vi måste förbereda oss för den hårda tid som ligger framför oss", förklarade May, ty "Europa kommer att störta samman i inbördeskrig i en närliggande framtid" (May 2007).

Föreställningen om ett nära förestående eller redan påbörjat inbördeskrig som närs i den kontrajihadistiska miljön genomsyrar Breiviks kompendium. Som jag sade i inledningen manar de ideologer vars texter han infogar inte nödvändigtvis till våld. Däremot ligger våldet ofta inbäddat i talet, som dess logiska konsekvens, i den stund ord omvandlas till handling. För Fjordman, som Breivik citerar, går vi mot en serie inbördeskrig i ett av multikulturalismen försvagat Europa. "Givet Europeiska unionens gränslösa natur kommer kriget knappast begränsas till en nation. Det kommer att skapa en dominoeffekt och muslimerna kommer åter att utvisas från Europa, efter storskaliga blodbad och miljoner döda kontinenten över" (Fjordman 2005, inkluderad i Breivik 20II, s. 74I). Begäret 
är uppenbart: genom krigets renande stålbad kommer den eftertraktade pånyttfödelsen. Breivik citerar Fjordman igen: "Genom att bokstavligen sätta kniven mot Europas strupe kommer den islamiska världen tvinga européerna att återskapa sig själva eller dö. Europa kommer att gå genom en turbulent period av smärtsam, men nödvändig pånyttfödelse” (Fjordman 2006, citerad i Breivik 20II, s. 742).

Det är till den, i grunden fascistiska, vision Breivik ansluter sig. Uppfylld av romantiska manliga krigarideal i termer av heroism, kamp, heder och ära vill han vara en del av en revolutionär nationalistisk uppgörelse med idén om jämlikhet och varje människas lika värde till förmån för ett monokulturellt, moralkonservativt och patriarkalt Europa som renat från främlingars och politiska motståndares fördärvliga inflytande reser sig ur dekadansen för att återta sin givna position som världssamfundets ledande civilisation. Visionen är ingalunda ny utan känns igen från den tidiga 1900-talshistoria som störtade världen i brand. Breivik är således inget mysterium utan en produkt av en politisk miljö som han i sin tur vill inspirera till efterföljd. 



\section{Epilog}

Mitt sakkunniganförande framfördes den 4 juni 20I2. Breivik lyssnade koncentrerat och när jag var framme vid konklusionen - att han inte var något mysterium utan kunde förstås som en fascist, som uppfylld av romantiska manliga krigarideal ville vara en del av en nationalistisk uppgörelse med idén om jämlikhet och varje människas lika värde till förmån för ett monokulturellt, moralkonservativt och patriarkalt Europa som renat från främlingars och politiska motståndares korrumperande inflytande skulle resa sig ur dekadansen för att återta sin givna position som världssamfundets ledande civilisation - nickade han nöjd. Jag hade förstått.

Då rätten gav Breivik möjlighet att kommentera min framställan, hade han endast ett tillägg att göra. Breivik ansåg att det inte riktigt kommit fram att det faktiskt fanns en militant nationalistisk våldstradition som han ville skriva in sig i. "Har det funnits ett motstånd i Norge efter andra världskriget fram till i dag?" frågade Breivik. "Har det skett politiskt motiverade våldsaktioner?" frågade han, retoriskt. "Jag tänkte ta några exempel på detta” ... eftersom "de flesta ju blev överraskade då de fann ut att det inte var islamister som genomförde 22/7". Breivik slog fast att "högerorienterade individer har brukat våld systematiskt. Det har varit väldigt många tillfällen. Det har varit uppemot 40 angrepp i Norge. Några har varit mot vänsterorienterade, några mot invandrare, så man kan nästan dela in dem i två kategorier: rasistiskt motiverade [attacker] och [attacker] mot vänsterorienterade människor." Dessa attacker, fortsatte Breivik, inkluderade åtminstone sju mord, femton mordbränder och fem bombattentat. Räknar man in hot och misshandel blir det mer än ett tusental angrepp. "I Sverige är antalet högre." Därefter började Breivik 
metodiskt lista en serie högerextrema attacker: mot Blitz' förstamajtåg, ett bokcafé, en moské, ett islamiskt center, mord på invandrare, afrikaner, en somalier, en marockan, en indier, år efter år. Breivik anförde att dessa våldsdåd kunde ses som "patetiska”, men att han såg förövarna som "hjältar" vars dåd han "beundrar" (Breivik 20I2b). Breivik hoppades att han med den 22 juli hade satt en ny standard för andra att överträffa: ”Jag har genomfört den mest sofistikerade, spektakulära och det mest brutala politiska attentat begånget av en militant nationalist i Europa sedan andra världskriget” (Breivik 20I2a).

Det bör betonas att jag inte var ensam om min bedömning av Breiviks politiska hemvist och bevekelsegrunder. De sex sakkunniga som kallats för att rätten skulle få ett kunskapsunderlag om de politiska miljöer och traditioner som influerat Breivik var påfallande eniga om att förövaren knappast var ensam om sina åsikter, att han politiskt kunde placeras i den fascistiska idétraditionen och att det inte var ovanligt att terrorister anser det rätt att döda för att uppnå den högre målsättning de vill förverkliga.

Domarna tog uppenbarligen intryck. Den 24 augusti 2012 dömdes Breivik till lagens strängaste straff, då han ansågs juridiskt tillräknelig och därför ansvarig för sina handlingar. Domarna fann förvisso hans åsikter förkastliga, men noterade att hans konspirationsteorier, tal om inbördeskrig och hans målsättning att gripa makten och fördriva muslimerna ut ur Europa florerade i högerextrema kretsar. De konstaterade att de termer Husby och Sørheim tagit för neologismer, som "nationaldarwinist", "självmordsmarxist" och "självmordshumanist", länge brukats i högerextrema miljöer och att hans hänvisning till Tempelherreorden snarast skulle ses som ett led i en programförklaring med avsikt att rekrytera fler till den kamp han såg sig vara en del av. ${ }^{2}$

I. Autonomt ungdomshus och samlingspunkt för vänsterradikal utomparlamentarisk aktivism i Oslo, grundat 1982 (hemsida: http://www.blitz.no).

2. Oslo tingrett - Dom. 22. juli-saken. Strafferett. Drap. Terror. Tilregnelighet. Forvaring. Straffeloven $\mathbb{S}$ I47 a forste ledd bokstav a og $b$, jf. straffeloven $\ I 48$ forste ledd I. straffalternativ og $\$ 233$ forste og annet ledd, og $\$ 233$ forste og annet ledd, $j f$. $\$ 49$, og straffeloven $\mathbb{S}$ I47a forste ledd bokstav b, jf. $\$ 233$ forste og annet ledd, og $\$ 233$ forste og annet ledd, jf. $\$ 49$. Oslo tingrett, 24 augusti 2012 i sak TOSLO-2OII-II8627-24. 


\section{Referenser}

Aderet, Ofer 20I2. Pioneer of Global Peace Studies Hints at Link between Norway Massacre and Mossad. Haaretz, 30 april 2012.

URL: http://www.haaretz.com/news/diplomacy-defense/pioneer-of-global-peacestudies-hints-at-link-between-norway-massacre-and-mossad-I.427385 (26 februari 2013)

Atkinson, Gerald L. 2004. Radical Feminism and Political Correctness, i Lind, William S. (red.) "Political Correctness." A Short History of an Ideology. Free Congress Foundation.

Bakel, Rogier van 2007. The Trouble is the West. Reason, november 2007.

Bawer, Bruce 2006. While Europe Slept. How Radical Islam is Destroying the West from Within. New York: Doubleday.

Bawer, Bruce 20I2. The New Quislings. How the International Left Used the Oslo Massacre to Silence Debate About Islam. New York: Broadside (e-bok).

Beam, Louis I992. Leaderless Resistance. The Seditionist, nr I2.

Besson, Sylvain 2005. La conquête de l'Occident. Le projet secret des islamistes. Paris: Seuil.

Boston, William 20II. Killer's Manifesto: The Politics Behind the Norway Slaughter.

Time, 24 juli $201 \mathrm{I}$.

URL: http://www.time.com/time/world/article/o,8599,208490I,oo.html (26 februari 2013)

Breivik, Anders Behring 20II. 2083. A European Declaration of Independence. Opublicerat kompendium, Breiviks "manifest".

Breivik, Anders Behring 20I2a. Öppningsanförande i Oslo tingsrätt, I7 april 2012.

Breivik, Anders Behring 20I2b. Anförande i Oslo tingsrätt, 4 juni 2012.

Børringbo, Klaus \& Færaas, Arild 20I2. 22. juli-rettssaken fredag 8. juni. Aftenposten, 8 juni 2012.

URL: http://www.aftenposten.no/nyheter/iriks/22juli/article6845785.ece (26 februari 2013)

Chesler, Phyllis 2005. The Death of Feminism. What's Next in the Struggle for Women's Freedom. Basingstoke: Palgrave.

Ekeroth, Ted 20II. "Blame Game" Gone Wrong, från bloggen Ted Ekeroth. Stoppa islamiseringen!, 25 juli $201 \mathrm{I}$.

URL: http://tedekeroth.se/20II/o7/25/blame-game-gone-wrong (26 februari 20I3) 
Fjordman [pseudonym för Peder Are Nøstvold Jensen] 2005. The Second Fall of Rome, från bloggen Fjordman, 21 november 2005.

URL: http://fjordman.blogspot.se/2005/II/second-fall-of-rome.html (26 februari 20I3)

Fjordman 2006. The Fall of France and the Multicultural World War, från bloggen Gates of Vienna, I8 april 2006.

URL: http://gatesofvienna.blogspot.se/2006/o4/fall-of-france-and-multiculturalworld.html (26 februari 2013)

Fjordman 2008a. Suggestions for the Future, från bloggen Gates of Vienna, 29 september 2008.

URL: http://gatesofvienna.blogspot.se/2008/o9/suggestions-for-future.html (26 februari 2013)

Fjordman 2008b. Defeating Eurabia. Egenpublicerad bok genom Lulu.com.

Fjordman 20II. The Noted Blogger Fjordman Discusses the English Defence League, från EDL:s webbnyheter EDL News, I9 juli 2011.

URL: http://englishdefenceleague.org/edl-news-2/82-the-noted-blogger-fjordmandiscusses-the-english-defence-league (26 februari 2013)

Gardell, Mattias 2003. Gods of the Blood. The Pagan Revival and White Separatism. Durham: Duke University Press.

Gardell, Mattias 20II. Islamofobi. 2 uppl. Stockholm: Leopard.

Goodrick-Clarke, Nicholas 1992. The Occult Roots of Nazism. Secret Aryan Cults and their Influence on Nazi Ideology. The Ariosophists of Austria and Germany, 1890-1935. New York: New York University Press.

Griffin, Roger 1993. The Nature of Fascism. London: Routledge.

Hirsi Ali, Ayaan 20Io. Nomad. En personlig resa genom civilisationerna. Stockholm: Bonnier.

Hirsi Ali, Ayaan 20I2. The Advocates of Silence. Citizen Times, II maj 2012. URL: http://www.citizentimes.eu/20I2/05/II/the-advocates-of-silence (26 februari 2013)

Husby, Torgeir \& Sørheim, Synne 20I2. Rettspsykiatrisk erklaring Breivik, Anders Behring

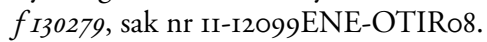

Kohlmann, Evan F. 2006. The Afghan-Bosnian Mujahideen Network in Europe. Rapport från Försvarshögskolan, Centrum för asymmetriska hot- och terrorismstudier (CATS).

Kozak, Diane 20Io. Exposing Eurabia. Westport: Beagle Books Publishing LLC.

Lind, William S. 2004. What is "Political Correctness"?, i Lind, William S. (red.) "Political Correctness." A Short History of an Ideology. Free Congress Foundation.

Lundberg, Johan 20II. Bjurwald blandar ihop högerkorten. Expressen, 25 juli 201 . URL: http://www.expressen.se/debatt/I.2509234/bjurwald-blandar-ihop-hogerkorten (26 februari 2013)

Madsen, Wayne 20II. Link Between Breivik and Israeli Mossad, från webbnyhetssidan Wayne Madsen Report via webbplatsen Alex Jones' Prison Planet, 24 juli 201 . URL: http://www.prisonplanet.com/wayne-madsen-link-between-breivik-and-israelimossad.html (26 februari 2013) 
May, Edward S. 2007. The UK and Scandinavia Counterjihad Summit, från bloggen Gates of Vienna, I4 april 2007.

URL: http://gatesofvienna.blogspot.se/2007/04/uk-and-scandinavia-counterjihadsummit.html (26 februari 2013)

McDonald, Jamie 2004. Political Correctness: Deconstruction and Literature, i Lind, William S. (red.) "Political Correctness." A Short History of an Ideology. Free Congress Foundation.

Omland, Ellen m.fl. 20I2. Breivik kan ha Aspergers syndrom, från NRK:s temasida 22.7. Rettssaken mot Anders Behring Breivik, 8 juni 2012.

URL: http://www.nrk.no/227/dag-for-dag/_-breivik-kan-ha-aspergerssyndrom-I.8I86695 (26 februari 2013)

Phillips, Melanie 2006. Londonistan. San Francisco: Encounter Books.

Raehn, Raymond V. 2004. The Historical Roots of "Political Correctness", i Lind, William S. (red.) "Political Correctness." A Short History of an Ideology. Free Congress Foundation.

Reconquista [pseudonym] 2009. From Titans to Lemmings. The Suicide of the White Race. Skrift från The Green Arrow (http://www.thegreenarrow.co.uk), en stödsida till British National Party.

Rosenqvist, Randi 20II. Föreløplig psykatrisk vurdering av forhold rundt Anders Behring Breivik. Kriminalomsorgen, Ila fengsel og forvaringsanstalt, I8 augusti 201 I.

Rustad, Hans 20II. Behring Breivik kopierte Una-bomberen, från webbnyhetssidan Document.no, 24 juli 201 .

URL: http://www.document.no/20II/o7/behring-breivik-kopierte-una-bomberen (26 februari 2013)

Trifkovic, Serge 2006. Defeating Jihad. How the War on Terror May Yet Be Won, In Spite of Ourselves. Salisbury: Regina Orthodox Press.

Tørrissen, Terje \& Aspaas, Agnar 20I2. Rettspsykiatrisk erklaring til Oslo tingrett, sak nr II-I88627MED-OTIR/o5.

Wakefield, Mary 2007. We are at War with all Islam. Spectator, 28 november 2007.

Ye'or, Bat [pseudonym för Gisèle Littman] 2005. Eurabia. The Euro-Arab Axis. Madison: Fairleigh Dickinson University Press.

Ye'or, Bat 20Ir. Europe, Globalization and the Coming Universal Caliphate. Madison: Fairleigh Dickinson University Press. 


\section{Arkiv förlags \\ Moderna klassiker}

Michel Foucault, Vansinnets historia under den klassiska epoken

Claude Lévi-Strauss, Det vilda tänkandet

Jürgen Habermas, Borgerlig offentlighet

Theodor W Adorno, Minima Moralia

Michel Foucault, Övervakning och straff

C Wright Mills, Den sociologiska visionen

Karl Polanyi, Den stora omdaningen

Per Nyström, Historia och biografi. Essäer och artiklar 1933-1989

Robert Brenner, Klasstrider och ekonomisk utveckling under feodalismen

Norbert Elias \& John L Scotson, Etablerade och outsiders

David Riesman, Den ensamma massan

Claude Lévi-Strauss, Spillror av paradiset

Paul Feyerabend, Mot metodtvainget

Raymond Williams, Tv. Teknik och kulturell form

Michel Foucault, Vetandets arkeologi

Eric J Hobsbawm, Massproducerade traditioner

Perry Anderson, Övergångar från antiken till feodalismen

Roland Barthes, Mytologier

Pierre Bourdieu \& Jean-Claude Passeron, Reproduktionen

Albert O Hirschman, Sorti eller protest. En fräga om lojaliteter

Elinor Ostrom, Allmänningen som samhällsinstitution

Marshall Berman, Allt som är fast förflyktigas

„Läs mer om böckerna på www.arkivmodernaklassiker.se» 